\title{
The drive behind the legends of South African science
}

\section{BOOK TITLE:}

Legends of South African science

\section{BOOK COVER:}

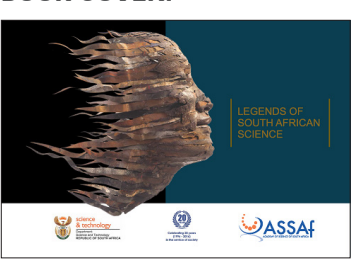

EDITOR:

Academy of Science of

South Africa (ASSAf)

ISBN:

9780994707673

\section{PUBLISHER:}

ASSAf, Pretoria; open access

\section{PUBLISHED:}

2017

\section{REVIEWER:}

Wieland Gevers

\section{AFFILIATION:}

Professor Emeritus, University of Cape Town, Cape Town, South Africa

\section{EMAIL:}

wieland.gevers@uct.ac.za

\section{HOW TO CITE:}

Gevers W. The drive behind the legends of South African science. S Afr J Sci. 2017;113(7/8), Art. \#a0221, 1 page. http://dx.doi. org/10.17159/sajs.2017/a0221

(c) 2017. The Author(s). Published under a Creative Commons Attribution Licence.
There is a long tradition of books which - through a compilation of biographies - seek to achieve a particular goal of the author that is distinct from the purely narrative-historical. Thus Plutarch's Lives of the Noble Greeks and Romans is a second-century series of biographies of famous men (and they were regrettably all men) designed to illustrate the moral virtues or failings which they had in common and to explore the influence of that elusive trait character - on the lives of his subjects. In the 16th century, Vasari wrote his Lives of the Artists, intending thereby to map the course of the 'rebirth' of European civilisation that we call the Renaissance.

The Academy of Science of South Africa (ASSAf) has now published a book comprising a set of biographical pieces on 53 eminent South African scholars and scientists who are all elected Academy Members but who in addition have been admitted to national orders by the Presidency, and/or have been awarded the country's largest and most prestigious individual research grant, the Harry Oppenheimer Award, and/or have been awarded the Science-for-Society Gold Medal of the Academy itself. The text is the work of a team of experienced writers who have mostly used an interview-style format to enliven their stories. A few of the subjects are deceased, and in these instances close colleagues have provided the necessary material. As might be expected, the tone of all the pieces is sympathetic rather than critical, with the special features of 'defining moments' and 'little-known information' often providing engaging revelations in each narrative.

Coming back to the issue of a possible underlying purpose or goal of this compilation, one is struck by the high level of energy and industry displayed by virtually all of these individuals. In the extreme case, we have the late Friedel Sellschop alternately using a standing and a sitting desk to keep awake during long nocturnal work sessions, with a swim in reserve in case these measures failed. The old adage of 'allocating a difficult task to the busiest person' is borne out by the incredible combination of intellectual and organisational work that most of these scholars have managed to stuff into their lives. One feels compelled to ask whether success breeds a confident appetite for work of all kinds, or whether it is the other way round - I suspect it is both of these mechanisms working in tandem.

South Africa has a small scholarly community relative to comparator countries in Europe and North America. It is likely that the small size of this community is another reason for the almost superhuman efforts that need to be made by local scholars to compete internationally in their science. And yet they also have made massive individual contributions to higher education and to science and innovation organisation and policy, especially so if one bears in mind that local teaching loads are also much heavier than those in more advanced countries (this aspect is regrettably underplayed in most of the narratives in this book).

Interestingly, most of the careers show a general unwillingness (or inability) of the people concerned to concentrate different activities into discrete phases - research activity is almost never 'let go' even if it is purely supervisory (there are of course a few notable exceptions). Some of the younger scholars have already been raised to senior administrative positions and are 'holding on for dear life' to the 'in-their-prime' phase of their research careers.

Because the writers of these narratives have used the journalistic art of the written-up interview rather than historiography or the information-crowded 'condensed CV', the stories are highly readable in the main, with some stand-outs and few if any failures. There is not an ivory tower in sight - the research fields are highly relevant to South Africa's economy in particular and its society in general. Even a highly distinguished cosmologist like George Ellis has extensively busied himself with the social and developmental problems here on earth. Whether it be the pressing issues of urban water supply and sanitation (Eugene Cloete and George Ekama), food security (Jill Farrant, Patricia Berjak and Walter Marasas), the forest-based economy (Michael and Brenda Wingfield) and school mathematics education (Jill Adler and Mamokgethi Phakeng), or the immense challenges of tuberculosis (Valerie Mizrahi and Paul van Helden) and HIV infection (Hoosen Coovadia, Quarraisha and Salim Abdool Karim, Helen Rees, Olive Shisana, Anna Coutsoudis and Glenda Gray), these scholars have achieved world-class status by expertly exploiting local niches doubling as serious national problems.

Some of the stories contain surprising or very amusing information. Who would have imagined that the immediate ex-president of the CSIR (Sibusiso Sibisi) has completed the Two Oceans, Comrades and Boston Marathons, and is a swimmer, cyclist and rower as well? That Bongani Mayosi and his now-professorial wife have competed in ballroom dancing in Oxford? That a botanist working on drought-resistant plants (Jill Farrant) is known as Mapula ('mother of rain') in her home province of Limpopo, and that every member of Phuti Ngoepe's immediate family has a PhD? Occasionally, the writers also provide a memorable turn of phrase. For example, Daya Reddy is described as a man 'who doesn't buckle under pressure but his knowledge of things that do buckle under pressure is second to none'.

I began this review by looking at the underlying goal of making a particular compilation of biographies. I concluded that the goal of this set of well-written (multi-author) interview-based accounts of selected ASSAf Members was to bring out the enormous energy and scholarly vitality displayed by every member of the entire group - something which seems to have its origin partly in the confidence borne of personal success, and partly in the local situation of a country forced to punch above its weight, so to speak.

I come now to the likely impact of this book. It is only by reading it through that the above-mentioned underlying message will be brought home - but how many in this busy day and age will actually do that? Individual stories are likely to be highly inspirational to young minds, suggesting that their serial re-publication in popular media may be a useful option. Coffee-table or journal-display usage in government, business and educational establishments may be helpful in spreading the message. The biggest and most direct impact will be on university students at both undergraduate and postgraduate levels, if only copies of the book can be made available to them in some way that is not extravagantly expensive yet efficient and effective. 